\title{
Primary primitive neuroectodermal tumor of the urinary bladder: a case report
}

\author{
Yasuyuki Kobayashi, Kenji Nishimura, Taigo Kato, Hidefumi Kishikawa, Yasuji I chikawa \\ Department of Urology, Hyogo Prefectural Nishinomiya Hospital, Nishinomiya, Japan \\ Correspondence: Yasuyuki Kobayashi. Address: Department of Urology, Hyogo Prefectural Nishinomiya Hospital \\ Rokutanji-cho, Nishinomiyacity, Japan. Telephone: 81-798-345-151. Fax: 81-798-235-151. \\ E-mail: ya_su_koba@yahoo.co.jp
}

Received: May 17, 2012

Accepted: July 23, 2012

Published: August 1, 2012

DOI : $10.5430 /$ jst.v2n4p53

URL: http://dx.doi.org/10.5430/jst.v2n4p53

\begin{abstract}
We report a rare case of primary primitive neuroectodermal tumor (PNET) of the urinary bladder. An 85-year-old man with hormone refractory prostate cancer was presented with gross hematuria. Abdominal computed tomography showed a tumor occupying the right lateral portion and neck of the bladder wall, while a cystoscopic examination revealed a bleeding, sessile globular tumor with no papillary features. Transurethral resection of the bladder tumor was performed. Histopathological results showed a small round cell tumor forming rosettes, further positive immunoreactivities for some neural markers and MIC gene product (CD99), which indicated PNET of the bladder. Four months after surgery, PNET of the bladder recurred with rapid growth and the patient died of tumor. To our knowledge, there have been only 8 such cases reported.
\end{abstract}

\section{Key words}

Primitive neuroectodermal tumor (PNET), Urinary bladder

\section{Introduction}

A primitive neuroectodermal tumor (PNET) is a malignant small round blue-cell tumor exhibiting a variable degree of neural differentiation, which arises outside the brain, spinal cord, and sympathetic nervous system ${ }^{[1]}$. In general, a PNET is a very aggressive tumor with rapid local infiltration combined with widespread metastasis ${ }^{[2,3]}$. Its aggressive behavior is reflected by a low 5 -year survival rate ranging from 60 to $90 \%$ when treated with surgical resection in combination with radiochemotherapy ${ }^{[3]}$. Recently such rare tumors with a highly malignant potential have been increasingly reported in various organs, including kidney ${ }^{[3]}$ and prostate ${ }^{[4]}$ in the field of urology. PNET of the urinary bladder is extremely rare, with only 8 cases previously reported to our knowledge. Herein, we present an additional case of a patient and review previously published reports.

\section{Case presentation}

An 85-year-old man with hormone refractory prostate cancer (HRPC) (poorly differentiated adenocarcinoma, Gleason score 10, clinical stage T3bN0M1b) was presented with gross hematuria. Urinary cytology findings were positive. 
Abdominal computed tomography showed a tumor occupying the right lateral portion and neck of the bladder wall, without evidence of an extravesical tumor or lymph node swelling (Figure 1a). A cystoscopic examination revealed a bleeding, sessile globular tumor with no papillary features. Chest X-ray findings showed no lung metastasis. The patient underwent transurethral resection of the bladder tumor (TURBT). Histologically, the tumor was composed of small round blue malignant cells without differentiation and with an intervening thin fibrovascular stroma (Figure 2a). The loosely cohesive tumor cells had scant levels of basophilic cytoplasm and highly polymorphic nuclei, with occasional rosette structures (Figure 2b). Immunohistochemical findings showed that the tumor cells were positive for the neural markers vimentin, neuron-specific enolase (NSE) (Figure 2c), and S-100 protein, while periodic acid-Schiff (PAS) staining showed the presence of glycogen. The stains for prostate specific antigen (PSA), $\alpha$-methylacyl-CoA Racemase (P504S), leucocyte common antigen, desmin, $\alpha$-smooth muscle actin, and cytokeratin 7 were negative. Furthermore, the tumor cells showed a significant reactivity for the MIC2 gene product (CD99) (Figure 2d). From these findings, the histological diagnosis was PNET of the bladder. No further treatment was initiated in consideration of the advanced age of the patient and HRPC terminal stage. Four months after TURBT, PNET of the bladder recurred (cystoscopic findings shown in Figure 1b) accompanied by rapid tumor growth, and the patient died of tumor metastasis. No autopsy was performed.

\section{Figure 1.}

a. Abdominal computed tomography showed a tumor occupying the right lateral portion and neck of the bladder wall.

b. A cystoscopic examination revealed a bleeding, sessile globular tumor in the bladder neck with no papillary features.
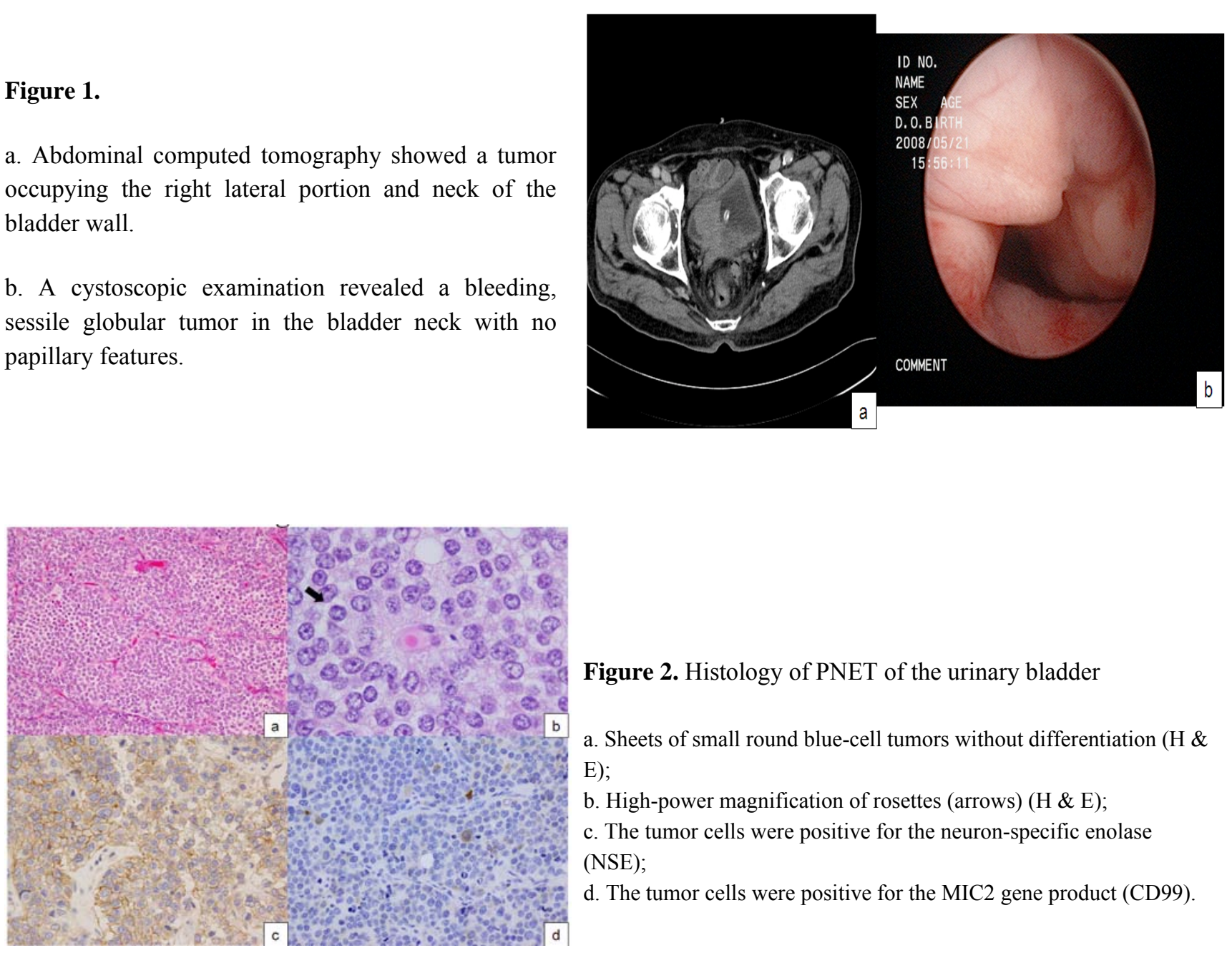

Figure 2. Histology of PNET of the urinary bladder

a. Sheets of small round blue-cell tumors without differentiation (H \& E);

b. High-power magnification of rosettes (arrows) (H \& E);

c. The tumor cells were positive for the neuron-specific enolase (NSE);

d. The tumor cells were positive for the MIC2 gene product (CD99). 


\section{Discussion}

A PNET of the urinary bladder is extremely rare, with only 8 cases previously reported. A review of those previous reports including the present case is shown in Table 1. The affected patients were 5 men and 4 women, with a mean age of 50.7 years old (range, 15-85). Five suffered from gross hematuria. Surgical treatment was performed in 8 of 9 cases (total cystectomy in 3, partial cystectomy in 1, TURBT only in 4). Adjuvant chemotherapy was performed in 2 of 3 total cystectomy cases, and those patients remained free of disease at follow-up examinations performed at 18 months and 3 years, respectively. In contrast, 3 of 4 patients treated by TURBT showed rapid recurrence and thereafter died of tumor. Therefore, a total cystectomy with adjuvant chemotherapy seems to provide long-term survival for PNET of the urinary bladder. The recommended chemotherapy regimen consists of vincristine, doxorubicin, and cyclophosphamide, alternating with ifosphamide and etoposide ${ }^{[5,6]}$.

Table 1. Reported cases of primary neuroectodermal tumor of the bladder

\begin{tabular}{|c|c|c|c|c|c|c|c|c|c|c|}
\hline \multirow{2}{*}{ No } & \multirow{2}{*}{$\begin{array}{l}\text { Author } \\
\text { (Journal) }\end{array}$} & \multirow{2}{*}{$\begin{array}{l}\text { Age/ } \\
\text { sex }\end{array}$} & \multirow{2}{*}{$\begin{array}{l}\text { Chief } \\
\text { complaint }\end{array}$} & \multirow{2}{*}{ Therapy } & \multirow{2}{*}{ Follow-up } & \multicolumn{5}{|c|}{ Immunohistochemical study } \\
\hline & & & & & & CD99 & S-100 & PAS & NSE & CK \\
\hline 1 & $\begin{array}{l}\text { Banerjee SS } \\
\text { (Histopathology, } \\
\text { 1997) }\end{array}$ & $21 / \mathrm{M}$ & $\begin{array}{l}\text { Microscopic } \\
\text { hematuria }\end{array}$ & $\begin{array}{l}\text { Total } \\
\text { cystectomy } \\
\text { chemotherapy }\end{array}$ & $\begin{array}{l}\text { NED: } \\
18 \text { months }\end{array}$ & $(++)$ & $(-)$ & $(+)$ & $(+/-)$ & $(-)$ \\
\hline 2 & $\begin{array}{l}\text { Angelo E } \\
\text { (J Urol, 1997) }\end{array}$ & $15 / F$ & $\begin{array}{l}\text { Gross } \\
\text { hematuria }\end{array}$ & $\begin{array}{l}\text { Partial } \\
\text { cystectomy } \\
\text { chemotherapy }\end{array}$ & NA & $(++)$ & $(-)$ & $(+)$ & $(+/-)$ & NA \\
\hline 3 & $\begin{array}{l}\text { Mentzel T } \\
\text { (Pathologe, } \\
\text { 1998) }\end{array}$ & $62 / \mathrm{M}$ & $\begin{array}{l}\text { High fever } \\
\text { attack }\end{array}$ & TURBT & $\begin{array}{l}\text { DOC: } \\
\text { 3weeks }\end{array}$ & $(++)$ & $\begin{array}{l}(+/ \\
-)\end{array}$ & $(+)$ & $(+/-)$ & $(-)$ \\
\hline 4 & $\begin{array}{l}\text { Desai S } \\
\text { (Histopathology, } \\
\text { 1998) }\end{array}$ & $38 / \mathrm{F}$ & $\begin{array}{l}\text { Gross } \\
\text { hematuria }\end{array}$ & $\begin{array}{l}\text { Total } \\
\text { cystectomy }\end{array}$ & NA & $(++)$ & $(-)$ & $(+)$ & $(++)$ & $(-)$ \\
\hline 5 & $\begin{array}{l}\text { Colecchia M } \\
\text { (Histopathology, } \\
\text { 2002) }\end{array}$ & $61 / \mathrm{F}$ & NA & No treatment & NA & $(++)$ & $(-)$ & $(+)$ & NA & $(-)$ \\
\hline 6 & $\begin{array}{l}\text { Krüger S } \\
\text { (Pathology, } \\
\text { 2003) }\end{array}$ & $81 / \mathrm{M}$ & $\begin{array}{l}\text { Urge } \\
\text { incontinence }\end{array}$ & TURBT & $\begin{array}{l}\text { DOD: } \\
\text { 2weeks }\end{array}$ & $(++)$ & $(-)$ & $(+)$ & $(++)$ & $(-)$ \\
\hline 7 & $\begin{array}{l}\text { Lopez-Beltran A } \\
\text { (J Clin Pathol, } \\
\text { 2006) }\end{array}$ & $21 / \mathrm{F}$ & $\begin{array}{l}\text { Gross } \\
\text { hematuria }\end{array}$ & $\begin{array}{l}\text { Total } \\
\text { cystectomy } \\
\text { chemotherapy }\end{array}$ & $\begin{array}{l}\text { NED: } \\
\text { 3years }\end{array}$ & $(++)$ & $\begin{array}{l}(+/ \\
-)\end{array}$ & $(+)$ & $(-)$ & )$^{(+/-}$ \\
\hline 8 & $\begin{array}{l}\text { Elinger J } \\
\text { (Urology, 2006) }\end{array}$ & $72 / \mathrm{M}$ & $\begin{array}{l}\text { Gross } \\
\text { hematuria }\end{array}$ & TURBT & NA & $(++)$ & NA & $(+)$ & NA & NA \\
\hline 9 & Our case & $85 / \mathrm{M}$ & $\begin{array}{l}\text { Gross } \\
\text { hematuria }\end{array}$ & TURBT & $\begin{array}{l}\text { DOD: } \\
\text { 3months }\end{array}$ & $(++)$ & $(+)$ & $(+)$ & $(+)$ & $(-)$ \\
\hline
\end{tabular}

NA: not available, TURBT: transurethral resection of the bladder tumor; NED: no evidence of disease; DOC: dead of other causes; DOD: dead of disease; PAS: periodic acid-Schiff; NSE: neuron-specific enolase; CK: cytokeratin.

The present diagnosis of PNET was established by histological and immunohistochemical analyses. Histologically, PNET is a malignant small round blue-cell tumor that exhibits a variable degree of neural differentiation, though all points on the spectrum share a predominantly lobular growth pattern ${ }^{[7]}$. For immunohistochemistry analysis, the most useful neural markers are NSE, vimentin, S-100, and synaptophysin, with staining detectable in up to $60 \%$ of the cases ${ }^{[8]}$. Further, the tumor cells show a strong expression of MIC-2 protein (CD99) ${ }^{[9]}$. In order to qualify for the designation of PNET, it is suggested that the tumor must show rosettes and be positive for at least two of the neural markers ${ }^{[7]}$. The detection of EWS-FLI1 type I fusion also allows us to exclude difficult differential diagnoses that cannot be separated Published by Sciedu Press 
immunohistochemically ${ }^{[10]}$. In the present case, positive staining for neural markers and CD99 was helpful for the diagnosis of PNET. Moreover, the lack of staining of muscle, lymphoid or neuroendocrine markers excludes rhabdomyosarcoma, lymphoma, and neuroendocrine carcinoma.

In the present case, a cystoscopic examination revealed a bleeding, sessile globular tumor with no papillary features, which are different features from those of a papillary tumor such as a common urinary transitional cell carcinoma. Initially, we clinically diagnosed the mass as a prostatic urethral tumor with bladder neck invasion from prostate cancer, because of the tumor appearance and the HRPC terminal condition of the patient. However, the histopathological finding was PNET of the urinary bladder that did not originate from the prostate gland as proved by the lack of staining of PSA and P504S. In the report of Gousse ${ }^{[6]}$, no papillary features of this kind of tumor are demonstrated in a cystoscopic examination. Thus, when no papillary tumor is discovered by cystoscopy, it is necessary to take PNET of the bladder into consideration as a differential diagnosis.

In conclusion, we report the 9th known case of PNET of the urinary bladder. Diagnosis of this type of tumor and effective therapy must be conducted as soon as possible because of its highly malignant potential.

\section{Acknowledgements}

I would like to express my gratitude to all those who gave me the possibility to complete this work.

I want to thank Department of Pathology, Hyogo Prefectural Nishinomiya Hospital, Nishinomiya, Japan for giving me valuable advice.

\section{References}

[1] De Alava E, Pardo J. Ewing tumor: tumor biology and clinical applications. Int J Surg Pathol. 2001; 9: 7-17. PMid:11469351 http://dx.doi.org/10.1177/106689690100900104

[2] Krüger S, Schmidt H, Kausch I, Bohle A. Primitive neuroectodermal tumor (PNET) of the urinary bladder. Pathol Res Pract. 2003; 199: 751-754. http://dx.doi.org/10.1078/0344-0338-00492

[3] Friedrichs N, Vorreuther R, Poremba C, Schafer KL, Böcking A, Buettner R, Zhou H. Primitive neuroectodermal tumor (PNET) in the differential diagnosis of malignant kidney tumors. Pathol Res Pract. 2002; 198: 563-569. http://dx.doi.org/10.1078/0344-0338-00303

[4] Kumar V, Khurana N, Rathi AK, Malhotra A, Sharma K, Abhishek A, Bahadur AK.. Primitive neuroectodermal tumor of prostate. Indian J Pathol Microbiol. 2008; 51: 386-388. http://dx.doi.org/10.4103/0377-4929.42518

[5] Banerjee SS, Eyden BP, McVey RJ, Bryden AA, Clarke NW. Primary peripheral primitive neuroectodermal tumor of urinary bladder. Histopathology. 1997; 30: 486-490. http://dx.doi.org/10.1046/j.1365-2559.1997.00524.x

[6] Gousse AE, Roth DR, Popek EJ, Cooley LD, Horowitz ME. Primary Ewing's sarcoma of the bladder associated with an elevated antinuclear antibody titer. J Urol. 1997; 158: 2265-2266. http://dx.doi.org/10.1016/S0022-5347(01)68231-4

[7] Fletcher CDM. Peripheral neuroectodermal tumors. In: Franz ME, Sharon W. Weiss (eds). Soft Tissue Tumors, 3rd ed Mosby Co St Louis. 1995; 1221-1250.

[8] Ellinger J, Bastian PJ, Hauser S, Biermann K, Müller SC. Primitive neuroectodermal tumor: rare, highly aggressive differential diagnosis in urologic malignancies. Urology. 2006; 68: 257-262. PMid:16904430 http://dx.doi.org/10.1016/j.urology.2006.02.037

[9] Lopez-Beltran A, Pérez-Seoane C, Montironi R, Hernández-Iglesias T, Mackintosh C, de Alava E. Primary primitive neuroectodermal tumor of the urinary bladder: a clinico-pathological study emphasizing immunohistochemical, ultrastructural and molecular analyses. J Clin Pathol. 2006; 59: 775-778. PMid:16803953 http://dx.doi.org/10.1136/jcp.2005.029199

[10] Ishii N, Hiraga H, Sawamura Y, Shinohe Y, Nagashima K. Alternative EWS-FL1 fusion gene and MIC2 expression in peripheral and central primitive neuroectodermal tumors. Neuropathology. 2001; 21: 40-44. PMid:11304041

http://dx.doi.org/10.1046/j.1440-1789.2001.00367.x 